\title{
Schmitt, Telos, the Collapse of the Weimar Constitution, and the Bad Conscience of the Left
}

\author{
Stephen Turner
}

The strange dispute over Carl Schmitt has deep roots. It begins with finger pointing about the failure of the Weimar Republic and presently takes the form of an oddly ferocious dispute over the reception of Schmitt in the United States. The debate over the reception touches on and is motivated by, without explicitly addressing, some of the most divisive issues in the realm of political thought, including issues about the political meaning of the twentieth century, the ambiguous significance of the Frankfurt School, the politically correct consensus of the academic Left, and the significance of Nazism. The finger pointing, which began as soon as the Weimar order collapsed, was over responsibility, especially the responsibility of the Left. The generation that lived through the collapse was haunted by the question. The dispute over the meaning of the twentieth century involved the merger of two central political narratives. The Left story, or one of them, makes the century into a struggle between the progressive forces of the Left and the evils of reaction, which the Left eventually (and after the war) more or less won and turned into the ideal of social democracy; its triumph was the expansion of the state against the opposition of liberals. The "liberal" or Left liberal view was that the progressive part of the century is to be found in the struggle between liberal democracy and its many worse enemies, including the Communist Left, Nazism, Catholic authoritarians, and fascism, a struggle which was won as a result of a humane accommodation with the legitimate demands of the Left for economic justice or at least economic security that (correctly) stopped short of socialism and provided freedom that (correctly) stopped short of libertarianism. The two narratives, deriving from sources originally hostile to one another, in the end come close to one another, in the vision of an economically just civil society with a strong state and a strong public sphere. For the politically correct, the great achievement of the twentieth century, represented in such thinkers as John Rawls and Jürgen Habermas, is the mutual accommodation of the best values of both traditions: justice and free political participation, under the benign restrictions of rationality.

Both parties to this accommodation also shared a particular trait: the tendency toward the moralization of politics that comes with the sense, especially vivid on the Left and central to the interwar Left, of being suspended between a future which lays slightly out of reach and a present in which politics is beset with oppositions which are seen as irrational, superstitious, inhumane, racist, religiously fanatical, and the like, which is to say morally inferior and intellectually blighted. Schmitt's thinking stands as the most unambiguous Other to this consensus. The fact that Telos publicized Schmitt and led the way in addressing the challenge of Schmitt has seemed, to more than a few bien pensants, to be a scandalous breach of scholarly morality.

There are those, however, both on the side of the Left and on the side of liberalism, who reject the standard story. Among liberals there was a conflict between those who were more concerned by the weaknesses of liberal democracy, and focused on its fragility, and those who focused on its imperfections but saw it as perfectable, usually by making it more egalitarian. Those liberals who focused on fragility tended to reject perfectability, which typically relied on an expanded state and a rationalistic view of politics, and emphasized the contingency and non-universality of the conditions of liberal politics. These liberals, such as Michael Oakeshott, were utterly incomprehensible to the 
adherents of the more conventional liberal account.[1] Some on the Left, notably Paul Piccone and Chantal Mouffe, also rejected this version of the triumph of Leftism as an "accommodation with managerial liberalism" (Piccone and Ulmen 2002). They were the ones who turned to authors from outside the Left and on the edge of liberalism as sources. Schmitt was the most prominent of these, and the use of Schmitt was, to both perfectability liberals and statist Leftists, scandalous, because he was, in the context of their versions of the century, unambiguously a foe. For the others, he was a source of insight into the inherent problems and conflicts of liberal democracy (conflicts he had relentlessly exposed), as well as the failures of past Left politics.

\section{| The Puzzling Discussion of the Schmitt Reception}

The conflict over the master narrative is an important part of the background to the strange dispute that has raged for the last few decades over the reception of Schmitt. But it cannot explain its extraordinary venom and intensity. But what does? The strangeness can hardly be overstated: there is no comparable discussion of any other thinker. Even Heidegger's Nazi period, which produced a small academic industry, did not produce a literature attacking those who had commented on Heidegger by dissecting their motives, accusing them of various political sins or secret political leanings of a totalitarian kind. But this kind of attack is the norm in the discussion of the Schmitt reception. Alan Wolfe claims that thinkers on the Left "impressed by his no nonsense attacks on liberalism and his contempt for Wilsonian idealism," see Schmitt as "someone who, very much like themselves, opposed humanism in favor of an emphasis on the role of power in modern society, a perspective that has more in common with a poststructuralist like Michel Foucault than with liberal thinkers such as John Rawls." The attitude of this Leftrepresented particularly by Telos, according to Wolfe, is that "anything would be better than Marx's contemporary, John Stuart Mill, and his legacy," and that "in turning to Schmitt rather than to liberalism, they have clung fast to an authoritarian strain in Marxism represented by such 20th century thinkers as V. I. Lenin and Antonio Gramsci” (Wolfe 2004).

Telos indeed published major translations of Schmitt, provided a forum for the defenders of Schmitt's intellectual significance and the coherence and legitimacy of his political reasoning, and also supplied opportunities for those who wished to rebut and anathematize Schmitt's "apologists." Even providing a forum for this discussion was controversial. Some members of the editorial board resigned over it. But the fury is still curious. Authoritarianism obviously has nothing to do with it, contra Wolfe. The critique of Schmitt is fundamentally about his association with and support of the Nazi regime. But this explains little about the venom on the Left against the mere discussion of Schmitt. Schmitt was not on the Left- his guilt belongs elsewhere. So why should anyone on the Left apologize for taking an interest in Schmitt, as distinct, say, from Lenin, who does belong to the Left, and whose guilt does belong there? And why is it not enough to denounce Schmitt as a Nazi, opportunist, and so forth, as all the "apologists" have? What is it about taking Schmitt seriously rather than merely denouncing him that produces this reaction?

Schmitt was not himself a Nazi ideologist- the ideology, in which he had little interest, was already invented before he supported Hitler. Yet he did, long before his association with the Nazis, make an argument that, in the light of the Holocaust, was incendiary: he noted that democracy created novel problems pertaining to minorities, especially those minorities who could never hope to attain power in a democratic state, and argued that the disruptive potential of these problems was such that democracy required a homogenous population.[2] It should be noted that these concerns, like the other issues he raised about liberal democracy, were extensions of concerns of contemporary liberals. In the United States, the issue was whether immigrants from Southern and Eastern Europe- among them Jews from the Pale of Settlement- could ever be assimilated and function as citizens in a liberal political order. His discussion of the conflict between liberalism and democracy can be compared to similar observations about the consequences for liberalism of working class parties made by liberals, such as Albert Venn Dicey ([1914] 1962), who also saw, in the development of purely interest based working class parties, the end of liberal democracy in the sense of government by discussion. Schmitt added to these observations by his reflections on the new phenomenon of totalizing parties, which gained legitimacy by promising something purer, but destroyed even the possibility of a degenerate kind of parliamentarism based on interest driven deal-making. These observations were and are not especially controversial, and certainly not "fascistic."

His contribution was at the level of meta-ideology, or philosophy: like Plato, and like Thomas Hobbes, whom he saw himself as following, Schmitt was a defender of the idea of the concentration of power. Perhaps he was 
also a worshiper of power, as one critic has plausibly claimed (Weiler 1994: 113). But this is hardly anomalous in the history of thought- Popper traced this worship of power throughout the history of western thought from Plato to Hegel, and found it in such contemporaries as Karl Mannheim. Moreover, totalizing and authoritarian tendencies are hardly absent in Mill (Cowling 1963), and the redistributive state that would be necessary to implement Rawlsian justice would be a powerful one as well. And it is a legitimate question as to whether Habermas's Kantianism, and Kantianism generally, does not necessarily culminate in totalizing authoritarianism in the name of reason rather than in the political fulfillment of reason. Why is Schmitt not treated as they are, namely as a convenient means to think through such issues?

\section{Who Killed the Weimar Republic?}

In what follows, I do not pretend to answer this question directly. I will consider instead one of the hidden sources feeding the Schmitt problem- the question of responsibility for the demise of the Weimar Republic. As I will show, real issues about the past are tangled up with differences over the nature of politics and the nature of knowledge of the political, and together these issues are important sources of the fury over Schmitt. All of these topics are issues for the Left for good reasons: one is that some commonplace Left ideas can be traced to Schmitt. Another is that Schmitt challenges a certain kind of moralistic Leftism and assigns it a degree of historical responsibility for the collapse of Weimar and thus for all that followed. The first issue has been discussed at some length in Telos itself. The Left has a deep and peculiar relation to Schmitt. His thinking continues to be an acknowledged and unacknowledged resource- often having passed through several hands-- for the contemporary Left. It is difficult to imagine, for example, feminist theory without the Schmittian argument that every distinction has the potential for becoming political- that words need to be understood in terms of who is affected, combated, refuted, or negated by them. And such iconic texts of the new Left as Marcuse's essay "Repressive Tolerance" ([1965]1969), which analyzed the notion of tolerance as itself repressive, would be empty if this thought were removed from them.

The Frankfurt School is at the center of the story of the Left's use of Schmitt. Not only did it supply lawyer critics of the Weimar constitution, but the critics included one of Schmitt's own students, Otto Kirchheimer. The other, Franz Neumann, used Schmitt's ideas extensively, and like Kirchheimer, hid this appropriation under a layer of dismissive references to Schmitt. These were the most intimate of enemies. Nor were they wild Italians or Leninist authoritarians. On the contrary, they were part of the most enlightened and "humanistic" Leftism, to use Wolfe's phrase. And the dependence on Schmitt did not end with these thinkers or with the end of Nazism- typically Schmittian themes are obvious in the critique of liberalism found in Habermas as well, especially in his discussion of the public sphere. Grand philosophical questions about the public sphere and issues of influence will be avoided here.

My concern will be with a more concrete problem within the Left: the remorse and soul-searching that followed the failure of the various socialist parties of Europe to stop fascism in their own countries and stop Hitler's military expansion. The questions are compelling on their own terms. Why did the SPD, which was the largest and most powerful party in the Weimar political order, fail, creating the political opportunity Hitler exploited? Why, with the example of Italian fascism before its eyes throughout most of the period, did the party not respond to the danger of a German form of fascism with a more effective political strategy of coalition formation? Why were no effective measures taken against the sworn enemies of the constitution when it was still possible? Here Schmitt is highly relevant. Schmitt's discussion of the demise of liberalism and its inevitable replacement by rule by a totalizing party bears directly, and ominously, on this problem. The Left welcomed, and the far Left welcomed most of all, the kind of party development that Schmitt had in mind under the heading of totalization, and was at best ambivalent about the suppression of the most aggressive totalizing party on the Left, the KPD (German Communist Party). And this suggests that the Left in Germany bears a part of the burden of responsibility for the collapse of the Weimar political order into Nazism.

\section{| Making the Problem Vanish: The Frankfurt School}

The Frankfurt School had a peculiar place in relation to the problem of responsibility. The Frankfurt School 
in general had little interest in politics or the law, and placed its analysis above the grubby level of party politics. But its two outlier lawyer members, Kirchheimer and Neumann, could not evade the political questions. They had written commentaries on the issues of the Weimar constitution while it was still in effect (Neumann [1930]1987; Kirchheimer [1930]1969). Kirchheimer's was a particularly compelling piece, which analyzed the contradictions of the Weimar Constitution, and damned it both for the contradictions and for the failure of the state to apply it in the most aggressively Left-wing way. Neumann had worked within the constitutional structure for legal reforms benefiting the workers, but had been frustrated by the limits of this approach. By 1932, as he confessed in a letter to Schmitt, he was wavering in his belief that socialism could be achieved without revolution, the idea that had, for the SPD, been one of the main justifications for cooperating with the Weimar order (Tribe 1987:21).

The standard Frankfurt School line on Nazism did not dwell on these matters, though there are some deep and odd connections. The psychoanalytic account of personality authoritarianism in the middle class filled many of the books that the 1960s Left was raised on, works such as Erich Fromm's Escape From Freedom (1941) and The Sane Society (1956). It is only a slight exaggeration to say that the lesson taught by these texts, and many others popular at the time, such as the prewar writings of Wilhelm Reich ([1933]1970; [1929]1972; 1972), was that the Nazi phenomenon and most of the ills of capitalist society were the more or less direct product of the sexual repression self-imposed by the petit bourgeoisie and especially the new middle classes of white collar workers. Needless to say, this account places historical responsibility on forces that had no connection to the activities of the Left, or to the political choices made by the members of the Frankfurt School themselves. Indeed, it completely exculpates the Left.

The actual role of the Left in the demise of the Weimar republic, especially the ultra-Left within the SPD and the Communists, was carefully airbrushed out of the story of the rise of Nazism itself. The actual role allowed for an alternative narrative- the suicide narrative- in which the Nazis were empowered and allowed into office by the political acts of both the Left and the non-Nazi Right and by a Chancellor and President who failed to act decisively against the anti-Democratic parties when action was required. This was Schmitt's narrative, and it is the narrative that haunted the émigrés: could the collapse of the Weimar Republic have been prevented? The question haunted Kirchheimer and Neumann. Kirchheimer himself asked the question in his major work, Political Justice: "If every link in the chain of repressive action at the disposal of the Weimar republic had been used differently [i.e. if the judiciary had not protected and lightly punished him], would the ascent to the summit of power have still been open to Hitler?" (1961:139). Neumann, similarly, included three hundred pages on the Weimar background in the draft of Behemoth ([1944]1966), only to leave all but forty of them on the cutting room floor. Much of what remained was about the finger pointing on the Left over the failures of the SPD and the tactics of the KPD,

\section{| The Bigger European Picture}

This story of the failure of the SPD to prevent the rise of Hitler has its own larger context, in the problems of the Left all across Europe in the interwar years. The core problem involved socialist morality. Socialist parties had argued for decades about the morality of participating in a "bourgeois" government, of allowing parliamentary democracy to be propped up with their support, and indeed of supporting any political goal other than the immediate realization of socialism. When the SPD was in power in Germany, it was uncomfortable- opposition and the pleasures of moral denunciation suited it much better. Parliamentary democracy or parliamentary politics were seen as instrumental activities- with the aim of destroying the present type of society and replacing it with a new socialist order.

The Left thus played a peculiar double-game not to their liking. As Neumann quoted Fritz Tarnow:

It seems to me that we are condemned both to be the doctor who earnestly seeks to cure and at the same time to retain the feeling that we are the heirs, who would prefer to take over the entire heritage of the capitalist system today rather than tomorrow. (Tarnow 1931, quoted in Neumann [1944]1966: 31).

Socialist politicians, though typically not their supporters, realized that the immediate enactment of socialisma concept that was very vague in the understanding of the leaders and followers alike, was impossible, and the enactment of socialism would produce a civil war. So those who took political responsibility, such as Léon Blum in France and Friedrich Ebert in Germany-attempted to govern as socialists who knew they did not have a mandate to transform society. Blum, indeed, saw himself as a healer, and tried to produce social peace and prosperity, through something like Roosevelt’s New Deal. 
One casualty of this double game was the last pretense that parliamentary government was operating normally. The basic requirements of representative democracy of a liberal kind, as Schmitt himself outlined them, were that representatives allow themselves to be persuaded with respect to the truth or validity of the arguments of other parliamentarians, and to take responsibility for explaining their actions to those they represent. This was precisely what the Left could not do. It depended on the hope for "socialism" and could not tell the workers that it was an impossible hope. Nevertheless, the SPD was pragmatic and open to compromise and back room deals. The EbertGroener pact at the beginning of the Weimar republic, which allowed the Army to suppress Red uprisings, was the most notorious of these. But the SPD also evaded political responsibility, took a role in government reluctantly, and adopted a rigid and narrow class interest strategy. Parliamentary discussion and writings in party papers degenerated into stagey performances. Schmitt's writings on parliamentarism placed this degeneration of liberal democracy in historical perspective.

Why should these observations be thrown out and tabooed along with Schmitt's later defenses of the Nazi regime? The answer- and more generally the fury over the reception of Schmitt- derives in part from the challenge which Schmitt as well as his "defenders" posed to the exculpation of the Left. Schmitt's message was that the Left played a large role in the suicide of the regime, both through the actions of the Communists, who were openly hostile to the constitution, and the SPD, which was tepid in support and unwilling to see the Communists repressed, but more importantly had behaved in parliament in a way that made a mockery of the idea of representation and discussion. As we have seen, the problem was structural: the SPD could neither tell the truth, namely that 'socialism' was not achievable in any realistically near future, if at all, nor could it speak this truth to its rigidly socialist worker followers, for fear of losing them to the Communists. So it was obliged, in parliament, to act out a pretense which satisfied the workers by enacting a drama of socialist devotion and purity, while defending their interests in a framework of politics and an economic order that they rejected in principle. The SPD was not an aberration. It was a condition of Left politics throughout Europe in the interwar years.

The very thing about the Left that made it attractive to idealists, its devotion to principles, also raised both the fascists and the Nazis above the grubbiness and compromise of what we now call liberal democracy. The Liberal parliamentary regimes of the times were unloved by those who lived under it in Continental Europe. They had few defenders and no ideological resonance. The German Liberals were of little political significance. Some of them longed for monarchy, calling themselves "Republicans by Necessity." On the Left, even moderate German workers marched to the chant of "A Republic is not so Grand, for Socialism we Take our Stand." The less moderate on the Right and the Left wanted the immediate end to the Republic, and the moderates - the SPD on the Left, had little room to act because they knew that the message of "not yet" was unpopular with their own constituents, who could, and did, turn to the Communists. Delivering the goods, in the form of redistributionist measures, such as pensions and unemployment payments, and strengthening the hand of the unions became their main aim. Failing to do even this meant the end of their balancing act, and ending the balancing act amounted to risking the end of the postwar republican constitution, or civil war, as Blum understood. The risk was real. In France, as in much of the rest of Europe since the 1920s, there were armed political factions ready for action. In each of the face-downs between the armed Left and the armed Right or the military the socialists lost and an authoritarian regime took over. Blum didn't need to believe in Liberal Democracy in order to realize that provoking violence would lead nowhere other than to catastrophe for the working class.

What was the alternative? Many of the political choices made by the Left in the interwar years did lead to catastrophe- to civil war and then to fascism or directly to fascism, as in Spain and Austria. Blum stands out as the best face of the Left- a Left that solved the problem of co-operation between the various factions of the Left (by the Communists supporting the Blum government but not participating in the cabinet), held power, avoided producing a reaction leading to a fascist regime, and accomplished something for the working class, in this case in the form of workers' rights. But this nevertheless ended badly for France- by defeat at the hands of the Germans and in a new world war.

The Austrian Left played its hand differently. The main Left party promoted the idea of a "democratic" Austria, and the Austro-Marxism of its leading theoretician, Otto Bauer, was later held out by humanist Marxists as a model. The party unified the Left by including in its Linz program of 1926 a clause about the "dictatorship of the proletariat" that read:

If, however, the bourgeoisie were to resist the radical social change which will be the task of the working class in government 
by systematically bringing economic life to a standstill, by violent revolt, by conspiracy with counter-revolutionary forces abroad, then the working class would be obliged to break the resistance of the bourgeoisie by the methods of dictatorship (quoted by Bruno Kreisky in Berg 2000: 69-70)

This language assuaged the militants, and kept the party from breaking into Communist and "Socialist" wings. But it also assured that the party would never come to power, that it would be feared and loathed by those inclined to resist. In his memoirs Kreisky called it "a terrible error" (Berg 2000: 69).

The fact that "dictatorship" was kept on the table as a legitimate option frightened the opposition and legitimated the dictatorship of Engelbert Dolfuss which followed the Austrian constitutional collapse. But the Austrian left was a totalizing party itself: Kreisky's subsequent recollections make this clear, while putting the most favorable possible gloss on it: "For many people, the Labor movement became their new, and true home. It enabled them to feel that their life, even with all its misery, had human dignity." And it did so by providing films, workers libraries, a chance to go out in the countryside, becoming a new Heimat (Kreisky in Berg 2000: 68-9).

The socialists in Austria and in the rest of interwar Europe had an instrumental view of politics- the point of participation in parliamentary politics, or government itself, was to advance socialism, not govern. They argued about the morality of any kind of participation in politics, and lamented the transitional situation they thought they were in: lacking the strength to bring about radical change, and having to prop up a system of parliamentary government they rejected and wished to abolish. So what happened in Austria? There was a brief "Civil War" involving armed workers, and Dolfuss announced a two front war against the Nazis and the Left, both of which he banned. The Dolfuss regime resembled some of the political remedies that have figured in the retrospective historical discussion of the collapse of the Weimar constitution, including Schmitt's original idea of expanding the powers of the state to suppress the anticonstitutional totalizing parties. It did not work in Austria: the Nazis assassinated Dolfuss and took power, leading to the Anschluss with Germany.

In Germany itself, the SPD was torn by the same dilemmas as Blum, in different degrees. They were pressed hard on the Left by the Communists. They routinely abdicated political responsibility in the 1920s, even when they were the leading parliamentary party. A change in heart by Stalin, who had learned from Hitler's takeover what risks a disunited Left posed, allowed for the creation of a popular front in France, in which the Communists supported a Socialist government but did not participate in it. Blum came to power as a result of this change in tactics. Neumann described the dilemma the Left faced at the end of the Weimar Republic, and how it understood this dilemma, in these terms:

The situation was desperate and called for desperate measures. The Social Democratic party could choose either the road of political revolution through a united front with the Communists under Socialist leadership, or co-operation with the semidictatorships of Brüning, Papen, and Schleicher in an attempt to ward off the greater danger, Hitler. There was no other choice. The Social Democratic party was faced with the most difficult decision in its history. Together with the trade unions, it decided to tolerate the Brüning government when 107 National Socialist deputies entered the Reichstag in September 1930 and made a parliamentary majority impossible. Toleration meant neither open support nor open attack. (Neumann [1944]1966: 31)

The German political crisis that eventually led to Hitler's Chancellorship was the proximal product of this deal breaking down with the refusal, on principle, of the Social Democrats to reduce benefits for the workers in the face of a fiscal crisis- a rerun, in slightly different form, of the parliamentary crisis led to the Dolfuss dictatorship.

\section{The Collapse}

One version of the collapse of the Weimar Republic casts the SPD in a benign light. The grand coalition that had resulted from the 1928 elections was faced with an economic crisis. The Center party, the other crucial member of this coalition, wanted an authoritarian, Presidential government, and to push out the SPD. When the fiscal situation of the state deteriorated in the face of increased unemployment claims, the SPD resisted placing the burden of suffering on the workers alone, the coalition collapsed, and no government had the backing of a parliamentary majority until the Nazis. Heinrich Brüning, the leader of the Center party, governed under the constitution by decree, with the tacit co-operation of the SPD, which feared that if it forced the government to resign, it would have brought the Nazis in to ensure its survival. The SPD, on this account, was merely standing up for its constituents and resisting 
the demonic designs of the Authoritarian Right under trying circumstances, with no good alternatives. Brüning, who was to become known as the Hunger Chancellor, was a villain who preferred authoritarian rule and suffering. The Rightward drift could not be stopped, and the Nazis fulfilled the plan of the bourgeois parties to suppress the Left. The Left resisted nobly, but resistance failed.

This airbrushed story allows Carl Schmitt to be allocated a specific and emblematic role: first as an advocate of the strengthening of the authoritarian aspects of the Weimar state, second as the enthusiastic supporter of the Nazi fulfillment of the original design. But the story is dubious and incomplete, and especially problematic in relation to Schmitt's own actions and writings. Who in this story was the defender of the Republic, anyway? What did being for the Republic mean in this context?

The SPD gave Brüning acquiescence. But it was more than acquiescence. The system of public opposition and backroom cooperation was, as a recent historical account has put it, "an enduring form of semi-parliamentary government based on dozens of private consultations between the chancellor and SPD leaders, where the SPD's need to respond to Communist attacks was balanced carefully against the chancellor's need to appear independent of the Left in the eyes of Hindenberg, the army command, and the parties of the moderate right" (Patch 1998: 351). The last pretense of a functioning government by parliamentary discussion vanished into this sham; or more precisely, the only aspect of republican government that remained was the pretense.

The issue which divided Brüning and Schmitt was the extent of the emergency powers contained in the Weimar constitution. Schmitt believed that circumstances might justify the temporary violation of any provision of the constitution, limited only by the requirement that when things returned to normal the constitution would be restored; Brüning thought this power was limited to the seven provisions listed in Article 48, Paragraph 2 (Patch 1998: 347; Bendersky 1983: 74-119). As a practical matter, using state power, meaning the military, to suppress the anticonstitutional parties was a possibility with a very limited application. In theory, the Nazis and the Communist could both be suppressed, or either one of them could be suppressed. In reality, the Army would have been reluctant to act against the far-right parties, but willing to take on the Communists. Suppressing the Communists would have taken a major prop of support for the Nazis off the table, and have allowed the Republic to be restored. The SPD however, which demanded the curbing of Nazi violence, would never have assented to the state taking on the Communistsdespite the willingness of the Communists to denounce the SPD as Social Fascists and worse. Insisting, as Schmitt did, that the constitution allowed for its own defense- that it was not a suicide pact- thus was a proposition with only one plausible application, precisely the application that the Left, however understandably, resisted.

The arrangement between Brüning and the SPD was doomed. When there was a vote in the Prussian state election, the Nazis and Communists improved their positions. Schmitt understood that even for the SPD, the constitution was a purely instrumental arrangement, that the constitution was unloved, a foreign imposition, along with most of the key political facts of Weimar, including the credit problems that made the fiscal crisis insoluble without doing what Brüning did. The Republic was discredited by these failures to agree and by the failure of the parties to persuade others of the need for agreement. The totalizing parties were destined to inherit the state, and behaved accordingly. It was only a question of which one. The Communists welcomed not only the end of the Weimar Republic, but Hitler himself. What Brüning feared, they embraced. "Herr Brüning has expressed it very clearly; once they (the Nazis) are in power, the united front of the proletariat will emerge and make a clean sweep of everything .... We are not afraid of the fascists. They will shoot their bolt quicker than any other government" (Adam Remmele, KPD leader, speaking in the Reichstag, October 1931, quoted in Hallas 1985). If the Communists had taken power they would have imposed the dictatorship of the proletariat without any scruples. The voters themselves chose to roll the dice. The SPD lost a crucial election in Prussia for control of the state. They continued in power as a caretaker government because neither they nor the other parties could come to terms on a coalition government. Prussia was an SPD stronghold, which they governed. The voters failed to stand by the SPD. The communists advanced. But the Nazi vote increased more. The end of the Weimar system was more or less assured.

The situation fulfilled Schmitt's gloomiest predictions. The totalizing parties had effectively destroyed the sham parliamentarism of Weimar, and were now making even the patchwork of coalitions and back-room arrangements collapse. The SPD had lost its capacity to enter into these deals, a capacity which was based on controlling enough of the vote of the proletariat to bargain. The dice had been rolled, and now there was a series of forced choices of a novel kind. The first choice was between a state which defended itself by banning parties even if this involved overriding the explicit constitution and acting on a theory of inherent powers to defend itself. When the state failed to do this, there was a second choice: between the totalizing parties that were capable of destroying the constitution. This was precisely the choice that the Communists themselves understood to be on offer. Schmitt, notoriously, chose 
to not only back the Nazis but join up in the totalization itself.

The Nazis were the only totalizing party that could have taken power without civil war. This is the main exculpatory fact. In retrospect, of course, the risk of open, violent political conflict, perhaps ending in a military dictatorship on the model of Józef Piłsudski, would have been better. But the options were not appetizing in any case. The 'defenders' have sometimes said more in the way of defense, notably about Schmitt's instrumental attitude to the Nazi regime and his irrelevance to the doctrines and practices of the real Nazis. This has the effect of normalizing his political choices- normalizing them to an exceptional situation. For a moralistic political thinker, this is to defend the indefensible. For a political thinker with a sense of what Weber called the tragic character of politics, it is an overwhelmingly powerful example of the risks inherent in the pacte diabolique with state violence that, according to Weber, is at the heart of politics. For such a thinker, it becomes possible to ask whether Schmitt was completely in error, and to entertain the thought that he drew a reasonable conclusion with a disastrous outcomeand that this time the moral risks of politics proved to be far greater than any previous one.

Wasn't Schmitt simply wrong in his political prognoses? Didn't liberal democracy prove to be the big winner among the political forms of the twentieth century? Isn't its supposed fragility merely an excuse for repression? A short glance at liberal democracy in the twentieth and early twenty-first century should be enough to answer this question: rivalry between class parties of Right and Left, coalition rule, the problem of the far Left, or Communist parties, which oppose the state and sometimes emerge as armed movements, the periodic intervention of the military when the parliamentary system is paralyzed, when prime ministers go beyond what the military deems acceptable, or fails to act against security threats, the irruption of nationalism and charismatic leaders, the threat, implicit or explicit, of civil war, minorities who fail to find a place for their grievances and interests in the party system- these are the actual conditions that have determined the course of politics in many of the "liberal democracies" of the world outside of Europe, North America, and Australia. But the major states of Europe did not degenerate into civil war. Was Blum simply deluded about this threat? Was Schmitt? The threats to liberalism Schmitt concentrated on were not fantasies, and the extreme Left contributed greatly to the risk profile of most of these states. The threats did not develop for two reasons. They were suppressed in the Postwar period by the United States, which invested mightily in the creation of a Europe of liberal democracies, operated clandestinely and through economic policy to support political pluralism, and by the fear of Soviet power that Europeans had, which the far Left never extricated itself from. Without the Cold War, matters might have been very different.

\section{Neumann and Kirchheimer: Two Paths}

Kirchheimer's role in relation to the collapse of the Weimar regime is well-documented. His critique of the Weimar constitution, "Weimar - and What Then?" ([1930]1969), left no doubt that he was on the side of those who regarded it as a failure, and among those asking "what now?" What did he learn from the collapse of the constitutional order? What did he regret? Not much, it seems. His account of the rule of law, in the 1930s, was focused on the hot button issue of the 1930s' Left, expropriation, for which the law was a significant obstacle. His account collapsed the rule of law into "accordance with the plan"- simultaneously replacing the bourgeois notion of law with executive decree and embracing the1930s ideology of planning. [3] He was nostalgic for the true opposition parties of the interwar era and the period before the First World War, and wrote extensively on what he called "the waning of the opposition," a Left version of the end of ideology thesis. He was contemptuous of the heterogenous, principle-less, vote-seeking parties of the postwar period. He called them catch-all parties. American parties were the paradigm of the catch-all party. He was deeply concerned to refute the claim that the post-war SPD had made any progress in recruiting in the middle class, arguing that the electoral gains of the post-1949 SPD were solely the result of losses from the KPD. [4] Nostalgia for the totalizing parties of the past was never far from the surface of his thought: "To the older party of integration," as he put it, "the citizen, if he so desired, could be closer. Then it was a less differentiated organization, part channel of protest, part source of protection, part purveyor of visions of the future. Now, in its linear descendant in a transfigured world, the catch-all party, the citizen finds a relatively remote, at times quasi-official and alien structure" (quoted by Burin and Shell 1969: xxix). This is a reminder, and a sinister one, of what the overcoming of alienation meant to the Old Left, both in theory and practice: not the elimination of Scarsdale angst, in the fashion of the 1960s New Left, but absorption into a party.

Kirchheimer was, at least, consistent: consistently hostile to both bourgeois democracy and the older liberal ideal 
of the rule of law: in 1930 he dismissed the problem of defending the Weimar order with the remark that "the point at which bourgeois democracy is transformed into bourgeois dictatorship is not clearly definable" ([1930]1969: 42). Like Schmitt, he decried the tyranny of the $50 \%$ plus 1 , with the observation that "The less agreement there is about the preconditions and the social principles of the society, the more the ruthless application of the majority principle tends to transform it into a technique for oppression, with the general will becoming a phantom” ([1930]1969: 40-1). His Political Justice (1961) was an attack on liberal ideals of the separation of law and politics. But it was sufficiently even-handed, especially by virtue of its attacks on Soviet political trials, that a naive reviewer could take it as liberal. [5] The basic reasoning, and even the style of even-handedness, was nevertheless characteristically Schmittian. The conclusion, that what counts as legal or political is a political matter, is Schmitt's thought as well as the doctrine of the Communists. This book had a familiar political motive. Kirchheimer was obsessed with the Rosenberg-Sobell case as an example of political justice, the great moralizing cause of the American Left for decades, either never grasping that the cause was based on lies, or not caring.[6]

The Old Left took care of its own. Talcott Parsons' convergence thesis was in full flower, and it provided a cover for sealing the deal. Columbia was full of ex-Communists such as Richard Hofstadter. Neumann had taught there before his death in a car accident in Switzerland. Kirchheimer was appointed in 1960 to Columbia, after a long stint at the New School, where he became the author of the emblematic moment of the Schmitt reception: he was placed on George Schwab's dissertation committee at the last moment to replace a director who had died. He used his power to have the dissertation, which later became the first survey of Schmitt's thought in English ([1970]1989), rejected, forcing Schwab to start again on a new dissertation topic and preventing him, temporarily, from publishing the book for fear of Kirchheimer's retribution. Schwab later described this attempt at suppression as an act of political justice (1988b: 449). It was also a means of burying the question of his own responsibility, a question that Schwab had raised by describing Schmitt's defense of the constitutional order, and by citing Kirchheimer's own attack on the constitution. Schwab notes in his description of the event, "the fact that Kirchheimer attempted to torpedo the Weimar constitution from his perspective as a left-wing Social Democrat did not ... prevent him from posing among his American colleagues as its defender" (1988a: 79). Schwab inadvertently ripped off the mask in his dissertation, and Kirchheimer was furious. "Of all my writings ... you had to single out those" he complained in the course of the dissertation exam (quoted by Schwab 1988a: 80). Kirchheimer may have regretted nothing, but he was well-aware that others thought he bore a burden of responsibility.

Neumann said far more about the collapse of the Weimar order. His masterwork on Nazi polyarchy, Behemoth, perhaps got its title as a response to Schmitt's 1938 defense of the regime as a Leviathan- Leviathan being the powerful monster of the sea, Behemoth the messier monster of the land. [7] The few pages of the original manuscript devoted to Weimar that remained in the published version deal directly with the problem of responsibility, and as part of a dispute within the Left. It is a remarkable exercise in finger pointing. None of it appeals to depth psychology. Although the text as a whole is larded with negative references to Schmitt, and dubiously attributes Nazi arguments about homogeneity to Schmitt (Neumann [1944]1966: 153), it is Schmitt as a defender of Nazism rather than Schmitt as a political thinker who is Neumann's target. The focus of the discussion of the collapse of the Weimar order is on the Left itself. Neumann quoted the comment of Otto Braun to the effect that the cause of the failure of the SPD and the Nazi seizure of power was a combination of Versailles and Moscow- the burden of having taken responsibility for signing the treaty and the machinations of the Moscow dominated KPD, but by extension the ultraLeft generally, which circumscribed the ability of the SPD to compromise. Neumann also appreciated the dilemma which prevented the leaders from developing a coherent reformist policy: "the threat that the workers might desert the reformist organizations and go over to the communist party," ([1944]1966: 19) and the fact that they were losing the young to the KPD ([1944]1966: 18).

Neumann's verdict was that the leaders of the SPD failed, and failed specifically to attract the new middle class of office workers, the salaried employees, to socialism ([1944]1966: 13, 17, 29, 32). This thought connects with the psychoanalytic story, as it was this class whose inner authoritarianism was a main object of the psychoanalytic account given by the Frankfurt School. Neumann himself made no connection to this thesis, and provided an alternative account. He also blamed the failure of the Republic on the lack of democratic values. But he acknowledged that the SPD did little to create the democratic consciousness that was needed to keep the constitution alive, seeing it only as "a first step to a greater and better future. And a transitory scheme cannot arouse much enthusiasm" ([1944]1966: 30). He admitted that the new idea in socialist constitutional theory, the "social Rechtsstaat" promoted by Kirchheimer, grew out of Schmitt's critique of the decisionlessness of the Weimar constitution itself, and attempted to provide a coherent purpose for it. But even this idea was never understood in the interwar Left as anything more than a 
transitory stage before socialism. Nor, as he conceded, did the economic justice ideas of the SPD ever persuade the salaried workers to join. Unlike Kirchheimer, Neumann died as he was moving toward a kind of uneasy liberalism (Jay 1986: xiii). From the start he had appreciated the moral ambiguities of politics in a way Kirchheimer never had. Where Kirchheimer remained on the side of the politics of faith, Neumann turned to the politics of skepticism.

\section{Failure of Imagination}

Neumann made a telling comment: "It was the tragedy of the Social Democratic party and trade unions to have had as leaders men with high intellectual qualities but completely devoid of any feeling for the condition of the masses and without any insight into the great social transformations of the postwar period" ([1944]1966: 32). This focus on leadership is strangely Weberian. Neumann did not give the Weberian explanation of this fact: that it was the structure of leader selection within the party itself that produced functionaries of this sort rather than leaders. But Neumann's comment indicates something more profound, and closely related to the problem of Schmitt. The SPD blundered into the failure of the Weimar constitution not through a lack of intelligence, but because, as Neumann saw, they failed to understand the social transformations of the time. So they persisted in a politics which moralized small differences in policy- by regarding matters of the funding of benefits as matters of principle so significant that it made sense to them to bring a government down over it in a situation in which the enemies of the constitution were rapidly gaining votes and support. They did not grasp that when coalitions collapsed and governments fell over minor issues things would not simply go on as before. If we ignore the drastic consequences of this particular constitutional failure, the actions of the Weimar Left begin to look very familiar. They are precisely the kinds of actions valued by the moralistic Left today. They stood up for principles, or at least were on the right side of, or they resisted-all acts of political virtue. They held on to their ideals, the ideal of socialism, and saw every political act as a compromise of those ideals. They had no respect for the political opinions of their opponents- the true mark of illiberalism.

In retrospect, of course, the Left's tepid support or outright hostility to the Weimar Republic, the embrace of sham parliamentarism, and the rest of it mark them out as underminers if not enemies of the Republic. The contribution of the SPD was tacitly agreeing not to strangle the Republic, and allowing the crisis to become more serious, while holding on to what power they had. They lacked the imagination and depth to think politically to do anything more, so they did not see that they were the authors of a catastrophe. Like managerial liberals today, such as Rawls, they believed that they had arrived at fundamental moral issues when they quibbled over details of policy. Kirchheimer believed that boldness would have consisted in demanding more. That it ended so badly was incomprehensible to them. Schmitt is incomprehensible to the present versions of this kind of cloistered political thinker, and for the same reasons: a lack of imagination and a moralistic focus on the trivial. The lesson that academic managerial liberalism and its Left counterpart wishes to draw from Schmitt is that thinking beyond these limits leads to disaster. But it would be more relevant, given the narrowness of conventional academic political correctness today, to consider the lesson that thinking in terms of the trivial can also have monstrous consequences.

The role of the Left in the destruction of the Weimar Republic was treated by the generation that lived through it as a family secret to be acknowledged only by changing the subject. Schmitt was a reminder of this episode, its Cassandra, to be anathematized but at the same time surreptitiously borrowed from. The denial of the role of the Left distorted the discussion of the historical meaning of Nazism, and through this distorted the academic discussion of politics that relied on the Left. The Frankfurt School was both the beneficiary and author of this collection of self-deceptions. It is no accident that in the project of liberating the Left from these ideas Telos turned back to Schmitt himself. The hysteria of the response shows that this was well-judged: Schmitt remains a powerful solvent of moralistic illusions, including those of the "public sphere" Left.

The usual question asked about the Schmitt reception is this: why should we be concerned, now, with a fascist theorist whose views have been decisively refuted by history, which has revealed the evil of the fascist option and the open vista of greater democracy, in the form of social democracy governing managed capitalism? The answer this question points to has to do with a lack of imagination and depth, and with an unwillingness to come to grips with the world- the social transformations, as Neumann put it- of the present. In the 1980s and 1990s, when the Schmitt discussion was fully underway in Telos, the world was returning to the kinds of conflicts and problems of the interwar years. The unions in Britain had shredded the Labour majority, bringing Margaret Thatcher to power. 
The demands of various constituents of the Democratic coalition in the US pushed Jimmy Carter into paralysis and brought Ronald Reagan to power with the backing of a problem minority which rejected the liberal consensus: the religious Right. The breakup of Yugoslavia brought the problem of ethnic minorities- and Schmitt's insight into the relationship between democracy and homogeneity-- back into focus. The genocides that followed the departure of the generation of authoritarian decolonizers in Africa, and the ethnic cleansing that followed democratization in the former Soviet republics both underscored the close connection between democracy and the problem of minorities. During this time, the Left in the United States descended into a long fugue of internecine moral one-upmanship about which groups was most oppressed, and wrote political theory and political philosophy as though the only important problem was to find new ways to make people equal.

If one opens the Schmittfrei pages of the journals that were the counterpart of Telos in the conventional disciplinary literatures of the time- journals like Ethics, Philosophy and Public Affairs, Economics and Philosophy, Political Theory, Theory and Society, Sociological Theory, and so forth, one finds paper after paper on the fine points of distributional questions, an elaborate attempt to accommodate the identity politics of the time, and an obsession with the public sphere. These were the concerns of the managerial liberalism of the time. They presumed a "normal" in which the state could manipulate the distribution of goods through policy and legitimate itself by accommodating endless demands for the recognition of deserving victim identities, and a public sphere concerned with negotiating the terms of payment. When Schmitt's issues intruded, they were in tame forms: the problem of politically unintegrated minorities was treated in terms of the novel values of inclusion and as a problem of the dominant group's infliction of otherness and victimization of those who were different. Although "homogeneity" was a taboo term, communitarianism and the active role of the state in promoting appropriate political values, which meant something similar, were acceptable. The fact that a more aggressively "social" democracy committed to values would itself generate new forms of the problem of minorities was registered only indirectly, and dismissed (e.g. in Pettit 1997, 96).

Time will tell whether this was a failure of imagination, and how large a failure of imagination it was. But it should be evident now that the crises of the present are crises of managerial liberalism. Schmitt would have been amused at the fact that the President who made the promotion of democracy the announced goal of American Foreign policy was followed by one who has made preventing genocide a major focus. The present economic crisis shows that the "normal" in terms of which policy-makers performed their manipulations over the last two American presidencies was an illusion- a Ponzi scheme. The failure of the West to create stable liberal democracies in Iraq and Afghanistan and the rise of the Chinese model show that the model of liberal democracy itself is based not so much on the nature of things, much less universal rationality, as on local traditions. And that the others are indeed "other."

\section{Acknowledgements}

Thanks to Gary Wickham for a useful organizational suggestion.

\section{Endnotes}

1. It is difficult to find a better example of this, or of academic invective, than Oakeshott's dismantling of the assumptions of his managerial liberal critics in "On Misunderstanding Human Conduct: A Reply to My Critics" (1976).

2. This argument, and its relation to Schmitt's own antisemitism, is discussed in Strong (2008).

3. The later account of the concept of the rule of law is mostly a discussion of the need to revise the concept to permit "the discretionary power of administration in the interest of public welfare," which, he charged, Dicey ignored out of middle-class myopia. This is the point at which managerial liberalism and Kirchheimer's left social democratic position converge in a legal program for the support of the administrative state devoted to what Weber called substantive justice. "The Rechtsstaat as Magic Wall," page 3, Otto Kirchheimer Papers, Box 2, Folder 95, German and Jewish Intellectual Émigré Collection, M.E. Genander Department of Special Collections and Archives, University at Albany, State 
University of New York (hereafter Kirchheimer Papers).

4. This is an important them of his postwar papers, for example, the untitled paper in Kirchheimer Papers, Box 2, Folder 83.

5. Max Rheinstein, the Weber translator and lawyer, said this in a review (1962/1963). But as his review and later correspondence with Kirchheimer reveals, he had no idea who Kirchheimer was, and did not even realize that he was a lawyer. Kirchheimer Papers, Box 1, Folder 133.
6. The Kirchheimer papers reveal that the Rosenberg and Sobell cases were of great interest to him. For Sobell see Box 8, Folder 10. Rosenberg is discussed inter alia in Political Justice.

7. The meaning of these terms is discussed at length in Weiler (1994: 37-45, 122). The relation between Schmitt and Behemoth is discussed in Kelly (2003: 258-97).

\section{References}

Bendersky, Joseph W. 1983. Carl Schmitt, Theorist for the Reich. Princeton, NJ: Princeton University Press.

Berg, Matthew Paul, ed. In collaboration with Jill Lewis and Oliver Rathcolb. 2000. The Struggle for Democratic Austria: Bruno Kreisky on Peace and Social Justice. Translated by Helen Atkins and Matthew Paul Berg. New York: Berghan Books.

Cowling, Maurice. 1963. Mill and Liberalism. Cambridge: Cambridge University Press.

Dicey, Albert Venn. [1914]1962. Law and Public Opinion in England: During the Nineteenth Century $2 \mathrm{~d}$ ed. London: Macmillan and Company.

Fromm, Erich. 1941. Escape from Freedom. New York: Farrar and Rinehart, Inc.

-----. 1956. The Sane Society. London: Routledge.

Hallas, Duncan. 1985. The Comintern. London: Bookmarks. Retrieved October 21, 2008 (http://www.marxists.org/archive/ hallas/works/1985/comintern/ch6.htm).

Jay, Martin. 1986. “Forward.” Pp. ix-xiv in The Rule of Law: Political Theory and the Legal System in Modern Society, edited by Franz Neumann. Leamington Spa, UK: Berg Publishers, Ltd.

Kelly, Duncan. 2003. The State of the Political: Conceptions of the Politics and the State in the Thought of Max Weber, Carl Schmitt, and Franz Neumann. Oxford: Oxford University Press.

Kirchheimer, Otto. "Papers." German and Jewish Intellectual Émigré Collection. M.E. Genander Department of Special Collections and Archives, University at Albany, State University of New York.

----.. 1961. Political Justice. Princeton, NJ: Princeton University Press.

-----. [1930]1969. "Weimar - and What Then? An Analysis of a Constitution.” Pp. 33-74 in Politics, Law, and Social Change: Selected Essays of Otto Kirchheimer, edited by Frederic S. Burin and Kurt L. Shell. New York: Columbia University Press.
Marcuse, Herbert. [1965] 1969. “Repressive Tolerance.” Pp. 95-137 in Robert Paul Wolff, Barrington Moore, Jr., and Herbert Marcuse. A Critique of Pure Tolerance. Boston: Beacon Press. Retrieved October 21, 2008 (http://www. marcuse.org/herbert/pubs/60spubs/65repressivetolerance. htm).

Neumann, Franz. [1944]1966. Behemoth: The Structure and Practice of National Socialism (1933-1944) 2d ed revised. New York: Harper.

----.. [1930]1987. “The Social Significance of the Basic Laws in the Weimar Constitution.” Pp. 27-43 in Social Democracy and the Rule of Law: Otto Kirchheimer and Franz Neumann, edited by Keith Tribe; translated by Leena Tanner and Keith Tribe. London: Allen and Unwin.

Oakeshott, Michael. 1975. On Human Conduct. Oxford: Clarendon Press.

-----. 1976. "On Misunderstanding Human Conduct: A Reply to My Critics." Political Theory 4(3):35367.

Patch, William L. 1998. Heinrich Brüning and the Dissolution of the Weimar Republic. Cambridge: Cambridge University Press.

Pettit. Philip 1997. Republicanism: A Theory of Freedom and Government. Oxford: Oxford University Press.

Piccone, Paul and Gary Ulmen. 2002. "Uses and Abuses of Carl Schmitt." Telos 122(3):3-32.

Reich, Wilhelm. [1933] 1970. The Mass Psychology of Fascism. Translated by Vincent R. Carfagno. New York: Farrar, Straus and Giroux.

-.---. [1929] 1972. "Dialectical Materialism and Psychoanalysis." Pp. 3-74 in Sexpol: Essays, 19291934, edited by Lee Baxandall; translated by Anna Bostock, Tom DuBose, Lee Baxandall. New York: Random House.

-----. 1972. Sexpol: Essays, 19291934, edited by Lee Baxandall; translated by Anna Bostock, Tom DuBose, Lee Baxandall. New York: Random House. 
Rheinstein, Max. (1962/1963) "Political Justice: The Use of Legal Procedure for Political Ends." reviewed by Otto Kirchheimer. The University of Chicago Law Review:197-203.

Schwab, George. [1970]1989. The Challenge of the Exception: An Introduction to the Political Ideas of C. Schmitt between 1921 and 1936 2d ed. Berlin: Dunker and Humblot.

-----. 1987. "Enemy or Foe: A Conflict of Modern Politics." Telos 72(Summer):194-201.

-----. 1988a. Carl Schmitt. Pp. 70-87 in Schmittiana: Beiträge zu Leben und Werk Carl Schmitts (Eclectica). Vol. 1, edited by Piet Tommissen. Brussel: Economische Hogeschool Sint Aloysius.

-----. 1988b. "Progress of Schmitt Studies in the EnglishSpeaking World.” Pp. 447-59 in Complexio Oppositorum: Über Carl Schmitt, edited by Helmut Quaritsch. Berlin: Duncker and Humblot.
Strong, Tracy. 2008. "Foreword: Carl Schmitt and Thomas Hobbes: Myth and Politics." Pp. vii-xxviii in The Leviathan in the State theory of Thomas Hobbes: Meaning and Failure of a Political Symbol, by Carl Schmitt, translated by George Schwab and Erna Hilfstein. Chicago: The University of Chicago Press.

Tribe, Keith. 1987. "Introduction." Pp. 1-26 in Social Democracy and the Rule of Law: Otto Kirchheimer and Franz Neumann, edited by Keith Tribe; translated by Leena Tanner and Keith Tribe. London: Allen and Unwin.

Weiler, Gershon. 1994. From Absolutism to Totalitarianism: Carl Schmitt on Thomas Hobbes. Durango, CO: Hollowbrook Publishing Co.

Wolfe, Alan. 2004. "A Fascist Philosopher Helps Us Understand Contemporary Politics." The Chronicle of Higher Education, April 2. Retrieved October 21, 2008 (http://chronicle.com/ free/v50/i30/30b01601.htm). 
